\title{
ANALISIS HUBUNGAN SUMBER POLUTAN DALAM RUMAH DAN SANITASI FISIK RUMAH DENGAN KEJADIAN ISPA DI WILAYAH KERJA PUSKESMAS WONGGEDUKU KABUPATEN KONAWE TAHUN 2019
}

\author{
Nani Yuniar ${ }^{1}$ Fithria $^{2}$ Rasni Hengki ${ }^{3}$ \\ 1,2,3 Fakultas Kesehatan Masyarakat,Universitas Halu Oleo Kendari \\ 1'naniyuniar@yahoo.co.id, ${ }^{2}$ fithria.ahmad@gmail.com, ${ }^{3}$ rasnihengki27@gmail.com
}

\begin{abstract}
Abstrak
Indonesia kasus Infeksi saluran pernapasan akut (ISPA) selalu menempati urutan pertama penyebab kematian bayi, dan menempati urutan kedua penyebab kematian pada anak-anak dan remaja.ISPA merupakan penyebab utama morbiditas dan motalitas penyakit menular di dunia.Penelitian ini bertujuan untuk mengetahui hubungan sumber polutan dalam rumah dan sanitasi fisik rumah dengan kejadian Infeksi saluran pernapasan akut (ISPA) di wilayah kerja Puskesmas Wonggeduku Kabupaten Konawe tahun 2019.penelitian ini iyalah survei analitik dengan desain cross sectionalstudy. Sampel dalam penelitian ini diperoleh 95 responden yang diperoleh dengan teknik pengambilan sampel simple random sampling. Hasil uji statistik pada tingkat signifikasi $\alpha=0,05$ diperoleh hasil, tidak ada hubungan yang bermakna antara ventilasi $(\rho$ value $=0.419)$ dengan kejadian penyakit ISPA. Ada hubungan yang bermakna antara kepadatan hunian ( $\rho$ value $=0.006$ ) dengan kejadian penyakit ISPA. Tidak ada hubungan yang bermakna antara pencahayaan alami rumah pada pagi hari ( $\rho$ value $=0,248)$, pada siang hari $(\rho$ value $=0,704)$, pencahayaan pada sore hari $(\rho$ value $=0,676)$ dengan kejadian penyakit ISPA. Ada hubungan yang bermakna antara keberadaan anggota keluarga perokok $(\rho$ value $=0.008)$ dan penggunaan anti nyamuk bakar $(\rho$ value $=0.004)$ dengan kejadian penyakit ISPA.
\end{abstract}

Kata kunci:Sumber polutan, sanitasi fisik rumah, infeksi saluran pernapasan akut (ISPA)

\begin{abstract}
Indonesia cases of acute respiratory tract infections (ISPA) always occupy the first cause of infant mortality, and occupy both causes of death in children and adolescents. ISPA is the leading cause of morbidity and mothality of infectious diseases in the world. This research aims to determine the link of source of pollutants in the home and physical sanitation of the house with the incidence of acute respiratory tract infection (ISPA) in the working area of District Wonggeduku Kabupaten Konawe in 2019. This research is an analytical survey with cross sectional study design. The samples in this study obtained 95 respondents obtained by simple random sampling sampling techniques. Statistical test results at a signification rate of $\alpha=0.05$ obtained results, there is nomeaningful relationship between ventilation ( $\rho$ Value $=0419$ ) with the incidence of ISPA disease. There is a meaningful relationship between the density of occupancy ( $\rho$ Value $=0.006$ ) with the incidence of ISPA disease. There is no meaningful link between the natural lighting of the house in the morning ( $\rho$ Value $=0.248$ ), during the day $(\rho$ Value $=0.704)$, daylighting in the afternoon $(\rho$ Value $=0,676)$ with the occurrence of ISPAdisease. There is a meaningful relationship between the existence of family members of smokers ( $\rho$ Value $=0.008$ ) and the use of anti-mosquito $(\rho$ Value $=0.004)$ with the occurrence of ISPA disease.
\end{abstract}

Keywords:Source of pollutants, home physical sanitation, acute respiratory infections (ISPA). 


\section{PENDAHULUAN}

Infeksi saluran pernapasan akut (ISPA) merupakan penyebab utama morbiditas dan motalitas penyakit menular di dunia.Hampir empat juta orang meninggal setiap tahun.tingkat mortalitas sangat tinggi pada bayi, anak-anak dan orang lanjut usia, terutama di negara dengan pendapatan rendah dan menengah. Begitu pula, ISPA merupakan salah satu penyebab utama rawat jalan dan rawat inap di fasilitas pelayanan kesehatan terutama pada bagian perawatan anak ${ }^{1}$.

Indonesia kasus ISPA selalu menempati urutan pertama penyebab kematian bayi, dan menempati urutan kedua penyebab kematian pada anak-anak dan remaja. Sebanyak $(36,4 \%)$ kematian bayi dan $(25,7 \%)$ pada anak-anak dan remaja yang masih masa pertumbuhan pada tahun 2008 , $(32,1 \%)$ pada tahun 2009, (18,2\%) pada tahun 2010, (38,8\%), pada tahun 2013 (25\%), dan (41,6\%) pada tahun 2018 disebabkan karena ISPA. Selain itu, ISPA sering berada pada daftar sepuluh penyakit terbanyak penderitannya di rumah sakit, diperoleh bahwa antara 20-30\% kematian anak disebabkan oleh ISPA².

Profil Kesehatan Provinsi Sulawesi Tenggara Infeksi Saluran Pernapasan Akut (ISPA) merupakan penyakit yang paling sering berada dalam daftar 10 (sepuluh) penyakit terbanyak di puskesmas maupun di rumah sakit. Tahun 2016 di Provensi Sulawesi Tenggara, terdapat $(2,22 \%)$ penderita ISPA dan pada tahun 2017 di Provensi Sulawesi Tenggara (2,39\%) penderita ISPA dan pada tahun 2018 terdapat (3,99\%) pend1erita ISPA ${ }^{3}$.

Data Dinas Kesehatan Kota Kendari tahun 2019 juga menunjukan trend kasus ISPA dari tahun 2016-2019. Pada tahun 2016 terdapat 47,34\% kasus ISPA, tahun 2017 meningkat menjadi 53,15\% kasus, selanjutnya pada tahun 2018 kembali meningkat menjadi 70,57\% kasus, namun pada tahun 2019 terdapat $66,18 \%$ kasus yang tercatat dari bulan Januari sampai bulan Juli ${ }^{4}$.

Data Puskesmas Wonggeduku, penyakit ISPA merupakan penyakit dengan kasus tertinggi yang sering terjadi sejak tahun 2016-2018. Adapan kasus yang terjadi pada tahun 2016 adalah 15\% kasus, tahun 2017 mengalami peningkatan menjadi 19\% kasus, dan pada tahun 2018 kembali meningkat menjadi $25 \%$ kasus $^{5}$.

Kecamatan Wongeduku memiliki batasbatas yaitu di sebelah Utara berbatasan dengan Kecamatan Wawotobi, sebelah Selatan berbatasan dengan Kecamatan Lambuya, sebelah Timur berbatasan dengan Kecamatan Pondidaha, serta di sebelah Barat berbatasan dengan Kecamatan Wonggeduku. Secara administratif, Ibukota Kecamatan Wonggeduku adalah Desa Puuduria. Desa Tetemotaha merupakan desa yang paling jauh dari ibukota kecamatan yaitu mencapai 10,2 kilometer, sedang yang paling dekat adalah Desa Duria Asi yang berjarak 0,85 kilometer ke ibukota Kecamatan ${ }^{6}$.

Kecamatan Wonggeduku merupakan salah satu dari wilayah Puskesmas Wonggeduku yang berada di Kabupaten Konawe dengan jumlah penduduk Kecamatan Wonggeduku pada Tahun 2019 berjumlah 13.862 jiwa.Penyakit ISPA di Pusat Kesehatan Masyarakat (Puskesmas) Wonggeduku, menduduki urutan pertama pada daftar 10 besar penyakit dengan pasien sebanyak 1.609 kasus $^{7}$.

Penelitian Safrizal (2017) tentang hubungan ventilasi, lantai, dinding, dan atap dengan kejadian ISPA pada masyarakat di Blang Muko menunjukkan bahwa ada hubungan antara ventilasi rumah, lantai, dinding, atap rumah dengan kejadian ISPA pada masyarakat. Penelitian I Gusti Agung Putu Mahendrayasa (2016) Faktor kondisi fisik rumah yang berhubungan secara signifikan dengan kejadian ISPA adalah faktor pencahayaan, ventilasi, lubang asap dapur, atap rumah dan perilaku merokok anggota keluarga ${ }^{8}$.

Keberadaan rumah sehat menjadi faktor penting yang bisa langsung berhubungan dengan lingkungan masyarakat itu tinggal.Kondisi rumah yang buruk bisa memudahkan terjadinya penularan penyakit ISPA. Kondisi lingkungan fisik seperti keberadaan anggota keluarga yang merokok, penggunaan obat nyamuk bakar, kepadatan hunian, luas ventilasi, jenis lantai, jenis dinding, intensitas pencahayaan, suhu rumah dan kelembaban rumah bisa mempengaruhi kejadian ISPA ${ }^{9}$.

Faktor resiko yang mempengaruhi seseorang terkena ISPA, yaitu faktor lingkungan, karakteristik individu dan perilaku. Faktor lingkungan meliputi pencemaran udara (asap rokok, polusi udara akibat hasil industri dan asap hasil pembakaran bahan bakar untuk memasak dengan konsentrasi yang tinngi). Faktor individu seperti umur, jenis kelamin dan tingkat pendidikan juga dapat mempengaruhi risiko kerentanan terkena ISPA ${ }^{10}$.

Penyakit ISPA masih sering terjadi dan bahkan menjadi penyakit dengan kasus yang paling tinggi hampir di setiap instansi kesehatan termasuk di Puskesmas Wonggeduku Kecamatan Wonggeduku. 
Sanitasi fisik dalam rumah dan polutan dalam rumah merupakan salah satu penyebab kejadian penyakit ISPA.Begitupun menurut penelitian Munaya tentang lingkungan fisik rumah merupakan salah satu faktor yang berhubungan dengan kejadian ISPA seperti, pencahayaan, kelembaban, dan jumlah anggota penghuni rumah yang tidak memenuhi syarat.Peneliti menyimpulkan ada hubungan yang bermakna antara jenis, kepadatan hunian, pencahayaan, keberadaan perokok dalam rumah dan penggunaan bahan bakar memasak dengan kejadian ISPA.Maka dari itu peneliti ingin melihat apakah ada hubungan antara sumber polutan dalam rumah dengan sanitasi fisik rumah dengan kejadian ISPA pada masyarakat di kecamatan Wonggeduku Kabupaten Konawe.

\section{METODE}

Merupakan penelitian kuantitatif dengan pendekatan cross sectional menggunakan metode survei. Penelitian ini bertujuan menjelaskan hubungan antar variabel,dengan tujuan untuk mendapatkan informasi secara mendalam tentang hubungan sumber polutan dalam rumah dan sanitasi fisik rumah dengan kejadian ispa di wilayah Puskesmas Wonggeduku Kabupaten Konawe tahun 2019. ${ }^{11}$.

Penelitian yang telah dilaksanakan didesain untuk menganalisis hubungan ventilasi, kepadatan hunian, pencahayan alami, keberadaan anggota keluarga perokok, penggunaan anti dengan Kejadian ISPA.

Populasi dalam penelitian ini adalah masyarakat di wilyah kerja puskesmas Wonggeduku yaitu 13.862 jiwa.Teknik pengambilan sampel berupa simple random sampling dengan besar sampel 95 responden.Pengumpulan data dilakukan dengan memberikan pertanyaan berupa kuesioner pada 95 responden wilayah kerja Puskesmas Wonggeduku. Analisis dilakukan dengan analisis uji Chi-Square dengan derajat kepercayaan $95 \%$ namun pada setiap variabel yaitu dengan Uji- Chi-Square (terdapat hubungan jika $\mathrm{p}<0,05$ ) pada 95 responden.

\section{HASIL DAN PEMBAHASAN}

Hasil analisis deskriptif tingkat pendidikan, pekerjaan, alamat masyarakat yang menjadi responden dalam penelitian di kecamatan wonggeduku kabupaten konawe tahun 2019 dapat dilihat pada table 1 berikut.

Tabel 1. Tingkat pendidikan, pekerjaan, alamat masyarakat di kecamatan wonggeduku kabupaten konawe tahun 2019

\begin{tabular}{|c|c|c|}
\hline Pendidikan & $\begin{array}{c}\text { Jumlah } \\
\text { (n) }\end{array}$ & $\begin{array}{c}\text { Persentase } \\
(\%)\end{array}$ \\
\hline SD & 34 & 35.8 \\
\hline SMP & 19 & 20.0 \\
\hline SMA & 28 & 29.5 \\
\hline S1 & 14 & 14.7 \\
\hline Total & 95 & 100 \\
\hline Pekerjaan & $\begin{array}{c}\text { Jumlah } \\
\text { (n) }\end{array}$ & $\begin{array}{c}\text { Persentase } \\
(\%)\end{array}$ \\
\hline PNS & 6 & 6.3 \\
\hline Wiraswasta & 12 & 12.6 \\
\hline Petani & 49 & 51.6 \\
\hline Tidak Bekerja & 28 & 29.5 \\
\hline Total & 95 & 100 \\
\hline Alamat & $\begin{array}{c}\text { Jumlah } \\
\text { (n) }\end{array}$ & $\begin{array}{c}\text { Persentase } \\
(\%)\end{array}$ \\
\hline Dewi-dewi & 4 & 4.2 \\
\hline Anggoro & 7 & 7.4 \\
\hline Bendewuta & 6 & 6.3 \\
\hline Wawosolo & 8 & 8.4 \\
\hline Puuduria & 7 & 7.4 \\
\hline Duria asi & 8 & 8.4 \\
\hline Wawonggole & 7 & 7.4 \\
\hline Lalohao & 7 & 7.4 \\
\hline Wawoone & 5 & 5.3 \\
\hline Wukusao & 5 & 5.3 \\
\hline Lalousu & 5 & 5.3 \\
\hline Tetemotaha & 6 & 6.3 \\
\hline Polandangi & 8 & 8.4 \\
\hline Tawarolondo & 6 & 6.3 \\
\hline Langgonawe & 6 & 6.3 \\
\hline Total & 95 & 100 \\
\hline
\end{tabular}

Hasil analisis menunjukkan pendidikan responden tertinggi SD sebanyak 34 orang, pekerjaan terbanyak petani sebanyak 49 orang yang terdistribusi merata di wilayah Kecamatan Wonggeduku.

Hubungan ventilasi rumah dengan kejadian penyakit ISPA di Kecamatan Wonggeduku Kabupaten Konawe tahun 2019.

Hasil analisis statistik ventilasi rumah dengan kejadian penyakit ISPA masyarakat di Kecamatan Wonggeduku disajikan pada table 2 berikut ini. 
Tabel 2. Hubungan ventilasi rumah dengan kejadian penyakit ISPA di Kecamatan Wonggeduku Kabupaten Konawe tahun 2019.

\begin{tabular}{|c|c|c|c|c|c|c|c|}
\hline \multirow{3}{*}{$\begin{array}{c}\text { Ventilasi } \\
\text { rumah }\end{array}$} & \multicolumn{4}{|c|}{ ISPA } & \multicolumn{2}{|c|}{ Total } & \multirow[t]{2}{*}{ PValue } \\
\hline & \multicolumn{2}{|c|}{$\mathrm{Ya}$} & \multicolumn{2}{|c|}{ Tidak } & & & \\
\hline & $\mathrm{n}$ & $\%$ & $\mathrm{n}$ & $\%$ & $\mathrm{n}$ & $\%$ & \\
\hline Baik & 27 & 69.2 & 12 & 30.8 & 39 & 100 & \\
\hline Kurang & 33 & 58.9 & 23 & 41.1 & 56 & 100 & 0.419 \\
\hline Total & 60 & 63.2 & 35 & 36.8 & 95 & 100 & \\
\hline
\end{tabular}

Ventilasi berfungsi sebagai sirkulasi udara dalam rumah karena udara yang segar dalam ruangan sangat dibutuhkan manusia. Gangguan pernafasan penghuni rumah dapat disebabkan oleh Ventilasi yang kurang baik.Penularan infeksi saluran pernapasan disebabkan karena kuman mengendap di dalam rumah akibat sirkulasi udara yang kurang baik.Sebaiknya ventilasi memenuhi syarat yang telah ditentukan dalam peraturan menteri Kesehatan yang menyatakan bahwa ukuran ventilasi minimal $10 \%$ dari luaslantai ${ }^{12}$.

Hasil penelitian diketahui bahwa dari rumah responden yang terkena ISPA di Kecamatan Wonggeduku yang mempunyai ventilasi yang memenuhi syarat sebanyak 56 rumah (100\%) dan ventilasi rumah yang tidak memenuhi syarat sebanyak 39 rumah (100\%), sedangkan responden yang tidak terkena ISPA mempunyai ventilasi yang memenuhi syarat sebanyak 23 rumah (41.1\%) dan ventilasi yang tidak memenuhi syarat sebanyak 12 rumah (30.8\%). Hasil Analisis statistik menunjukkan bahwa kejadian ISPA di kecamatan wonggeduku tidak disebabkan oleh ventilasi rumah masyarakat.

Hal ini dapat disebabkan ventilasi atau jendela pada rumah responden rata-rata memiliki ukuran cukup baikdan telah memenuhi syarat yaitu $\geq 10 \%$ dari luas lantai rumah. Kemudian jendela selalu dibuka pada setiap hari sehingga proses pertukaran udara pada rumah lancar. Dimana fungsi ventilasi sebagai jalur saluran keluarnya polusi dari dalam rumah. Jika ruangan yang berpolusi tidak terdapat ventilasi, maka asap maupun polusi tersebut akan terperangkap didalam ruangan dan ruangan menjadi pengap sehingga hari, sehingga proses keluar masuknya udara tidak baik. Ventilasi merupakan proses penyediaan udara segar ke dalam dan mengeluarkan udara kotor dari suatu ruangan tertutup secara alamiah. Dengan adanya ventilasi yang baik maka udara segar dapat dengan mudah masuk ke dalam rumah. Ventilasi yang kurang baik dapat membahayakan dalambernapas. Adanya pertukaran udara yang baik, terjaganya kadar Oksigen di dalam rumah serta udara yang segar tentu akan berpengaruh terhadap kesehatan para penghuni yang tinggal di rumah tersebut. Penelitian ini sejalan dengan penelitian Agustina (2018) didapatkan hasil tidak ada hubungan antara kejadian ISPA dengan ventilasi masyarakat yang tidak memenuhi di Kupang sebesar 25,7\%. Hal ini disebabkan pada pagi harimasyarakat tidak membuka ventilasi, selain itu kebanyakan menggunakan tirai horden pada ventilasi sehingga cahaya yang masuk ke dalam rumah kurang maksimal ${ }^{13}$.

Penelitian ini sejalan dengan penelitian Adhasari Agungnisa(2019)yang menyatakan bahwa kejadian ISPA tidak ada hubungannya dengan ventilasipada masyarakat di Desa Kalianget Timur.selain itu, ventilasi rumah di Desa Kalianget Timur rata-rata dibuka pada pagi dan siang hari ${ }^{14}$.

Penelitian ini juga sejalan dengan penelitian Marhamah Dkk., 2013 menunjukkan hasil serupa, bahwa ventilasi rumah tidak memiliki hubungan yang bermakna dengan kejadian ISPA pada balita di Desa Bontongan dikarenakan sebagian besar rumah tinggal responden berdinding papan kayu sehingga sela-sela papan kayu dapat berfungsi sebagai lubang udara ${ }^{15}$.

\section{Hubungankepadatan hunian dengan kejadian penyakit ISPA di Kecamatan Wonggeduku Kabupaten Konawe tahun 2019.}

Hasil analisis statistik kepadatan hunian dengan kejadian penyakit ISPA di Kecamatan Wonggeduku disajikan pada table 3 berikut ini.

Tabel 3. Kejadian penyakit ISPA dan hubungannya dengan kepadatan hunian di Kecamatan Wonggeduku Kabupaten Konawe tahun 2019.

\begin{tabular}{|c|c|c|c|c|c|c|c|}
\hline \multirow{3}{*}{$\begin{array}{l}\text { Kepadatan } \\
\text { hunian }\end{array}$} & \multicolumn{4}{|c|}{ ISPA } & \multirow{2}{*}{\multicolumn{2}{|c|}{ Total }} & \multirow{3}{*}{ Pvalue } \\
\hline & \multicolumn{2}{|c|}{$\mathrm{Ya}$} & \multicolumn{2}{|c|}{ Tidak } & & & \\
\hline & $\mathrm{n}$ & $\%$ & $n$ & $\%$ & $n$ & $\%$ & \\
\hline Padat & 44 & 74.6 & 15 & 25.4 & 59 & 100 & \\
\hline $\begin{array}{l}\text { Tidak } \\
\text { padat }\end{array}$ & 16 & 44.4 & 20 & 55.6 & 36 & 100 & 0.006 \\
\hline Total & 60 & 63.2 & 35 & 36.8 & 95 & 100 & \\
\hline
\end{tabular}

Persyaratan kepadatan hunian untuk rumah sehat tercantum dalam peraturan Menteri Kesehatan RI nomor 1077/MENKES/PER/V/2011 tentang pedoman penyehatan udara dalam rumah.Apabila luas rumah dibagi jumlah penghuni adalah $<8 \mathrm{~m}$ 
makadinyatakan rumah tersebut padat tidak memenuhi syarat ${ }^{16}$.

Menurut Achmadi (2014) penularan penyakit khususnya melalui udara akan semakin cepat jika kepadatan rumahsemakin tinggi.Anggota keluarga yang menghirup udara sama dan sudah tercemar akibat adanya anggota keluarga yang menderita gangguan pernafasaan yang disebabkan oleh virus akan mudah terserang. Artinya, penyakit yang diakibatkan oleh pencemaran udara seperti gangguan pernafasan atau ISPA sangat mudah untuk ditularkan apabila penghuni dalam rumah Semakin padat. ${ }^{17}$

Penularan penyakit baik langsung maupun tidak langsung terjadi akibat berkembangbiaknya bibit penyakit yang disebabkan oleh kepadatan hunian yang tidak memenuhi syarat sehingga menyebabkan kelembaban ruangan tinggi. Berkurangnya ruang bagi setiap penghuni rumah diakibatkan oleh jumlah penghuni rumah yang padat sehingga kontak antar penghuni lebih sering dan lebih lama.Kejadian tersebut akan memudahkan terjadinya penularan pada penghuni yang lain jika ada penderita ISPA di dalamrumahtersebut. sehinggainfeksi silang kepada penghuni lainnya kemungkinan dapat terjadi (Taha, $2018)^{18}$

Hasil penelitian diketahui bahwa rumah penduduknya memilki kepadatan hunian yang padat sebanyak 59(62.1\%), dan terdapat 36 (37.9\%) tidak memiliki hunian yang padat. Hasil analisis statistic menunjukkan ada hubungan antara kepadatan hunian dengan kejadian ISPA pada masyarakat di Kecamatan Wonggeduku Kabupaten Konawe denganpvaluesebesar 0.006 .

Hasil penelitian menunjukkan penyebab rumah responden memiliki kepadatan hunian yang berlebih ini di sebabkan karena satu rumah di huni dengan dua KK yang tinggal sehingga luas bangunan tidak sebanding dengan jumlah penghuni yang tinggal dalam rumah dan juga sebagian rumah responden memang tergolong kecil untuk di huni ini di sebabkan karena kondisi ekonomi yang masih kurang sehingga belum dapat merenovasi rumah menjadi sehat dan layak huni. akibatnya,penghuni rumah akan semakin mudah tertular penyakit ISPA.

Penelitian ini juga sejalan dengan Wahyuningsih Dkk., 2017 yang menyatakan bahwa dari hasil uji statistik ada hubungan kepadatan hunian dengan kejadian Infeksi Saluran pernafasan Akut (ISPA) pada balita dimana diperoleh nilai $p$-value 0,000atau $p$-value $>0,05$ di Wilayah Pesisir Desa Kore Kecamtan Sanggara Kabupaten Bima ${ }^{19}$.

Penelitian ini sejalan dengan Hogar., Dkk 2018, yang mengatakan di Ghana Asap kumparan nyamuk, bagaimanapun, berpotensi menjadi sumber polusi udara dalam ruangan dengan implikasi untuk infeksi saluran pernapasan akut (ISPA) dan penyakit lainnya. Analisis chi square menunjukkan bahwa perbedaan yang diamati secara statistik signifikan $\left(x^{2}=4,25 ; p=\right.$ $0,04)^{20}$. Hasil analisis statistik pencahayaan alami pada pagi, siang, dan sore dengan kejadian penyakit ISPA di Kecamatan Wonggeduku disajikan pada table 4 berikut ini.

Kejadian penyakit ISPA dan hubungannyadengan pencahayaan alami rumah di Kecamatan Wonggeduku Kabupaten Konawe tahun 2019

Table 4. Hubunganpencahayaan alami pada pagi, siang, dan sore dengan kejadian penyakit ISPA di Kecamatan Wonggeduku Kabupaten Konawe tahun 2019.

\begin{tabular}{|c|c|c|c|c|c|c|c|}
\hline \multirow{3}{*}{ pagi } & \multicolumn{4}{|c|}{ ISPA } & \multirow{2}{*}{\multicolumn{2}{|c|}{ Total }} & \multirow{3}{*}{ Pvalue } \\
\hline & \multicolumn{2}{|c|}{$\mathrm{Ya}$} & \multicolumn{2}{|c|}{ Tidak } & & & \\
\hline & $\mathrm{n}$ & $\%$ & $\mathrm{n}$ & $\%$ & $n$ & $\%$ & \\
\hline TMS & 20 & 74.1 & 7 & 25.9 & 27 & 100 & \multirow{3}{*}{0,248} \\
\hline MS & 40 & 58.8 & 28 & 41.2 & 68 & 100 & \\
\hline \multirow[t]{2}{*}{ Total } & 60 & 63.2 & 35 & 36.8 & 95 & 100 & \\
\hline & \multicolumn{4}{|c|}{ ISPA } & \multirow{2}{*}{\multicolumn{2}{|c|}{ Total }} & \multirow{3}{*}{ Pvalue } \\
\hline \multirow[t]{2}{*}{ Siang } & \multicolumn{2}{|c|}{$\mathrm{Ya}$} & \multicolumn{2}{|c|}{ Tidak } & & & \\
\hline & $\mathrm{n}$ & $\%$ & $\mathrm{n}$ & $\%$ & $n$ & $\%$ & \\
\hline TMS & 19 & 67.9 & 9 & 32.1 & 28 & 100 & \multirow{3}{*}{0,704} \\
\hline MS & 41 & 61.2 & 26 & 38.8 & 67 & 100 & \\
\hline \multirow[t]{2}{*}{ Total } & 60 & 63.2 & 35 & 36.8 & 95 & 100 & \\
\hline & \multicolumn{4}{|c|}{ ISPA } & \multirow{2}{*}{\multicolumn{2}{|c|}{ Total }} & \multirow{3}{*}{ Pvalue } \\
\hline \multirow[t]{2}{*}{ Sore } & \multicolumn{2}{|c|}{$\mathrm{Ya}$} & \multicolumn{2}{|c|}{ Tidak } & & & \\
\hline & $\mathrm{N}$ & $\%$ & $\mathrm{n}$ & $\%$ & $n$ & $\%$ & \\
\hline TMS & 21 & 67.7 & 10 & 32.3 & 31 & 100 & \multirow{3}{*}{0,676} \\
\hline MS & 39 & 60.9 & 25 & 39.1 & 64 & 100 & \\
\hline Total & 60 & 63.2 & 35 & 36.8 & 95 & 100 & \\
\hline
\end{tabular}


Cahaya matahari efektif membunuh bakteribakteri pathogen dalam rumah.oleh karena itu, rumah yang sehat harus memiliki jalan masuk cahaya yang cukup.Membiarkan cahaya matahari pagi masuk ke dalam rumah dapat mematikan kuman karena cahaya matahari pagi tersebut banyak megandung sinar ultraviolet yang diyakini bersifat germicid ${ }^{21}$.

Lux meter digunakan untuk mengukur pencahayaan dalam ruangan.Pencahayaan dikatakan tidak memenuhi syarat bila intensitas $<60$ lux, dan memenuhi syarat bila intensitas $\geq 60$ lux.Pencahayaan alami merupakan pencahayaan yang diukur dalam penelitian yang telah dilaksanakan.Penerangan rumah secara alami oleh sinar matahari melalui jendela, lubang angin dan pintu dari arah timur di pagi hari dan barat di sore hari disebut Pencahayaan alami ${ }^{22}$.

Hasil penelitian menunjukkan kejadian ISPA tidak berhubungan signifikan pencahayaan alami di dalam rumah masyarakat di Kecamatan Wonggeduku Kabupaten Konawe.Pencahayaan sudah cukup baik disebabkan karena kebanyakan rumah responden berbahan dasar papan sehingga pada selah-selah papan tersebut masuk cahaya matahari.

Hasil penelitian diketahui bahwa rumah penduduk di Kecamatan Wonggeduku Kabupaten Konawe yang memilki kondisi pencahayaan yang tidak memenuhi syarat pada pagi hari sebanyak 21 responden, pada siang hari sebanyak 23 responden dan pada sore hari sebanyak 31 responden. Sedangkan kelompok responden yang memiliki pencahayaan memenuhi syarat pada pagi hari sebanyak 74 responden, pada siang hari sebanyak 67 responden dan pada sore hari sebanyak 64 responden. Pada kondisi rumah responden, pencahayaan alami masuk pada jendela dan lubanglubang kecil pada dinding bagian rumah.Sehingga berdasarkan hasil penelitian banyak rumah responden memiliki pencahayaan alami rumah yang sudah cukup bagus dimana sinar matahari bisa langsung masuk ke dalam rumah melalui selah-selah dinding rumah.Dengan adanya pencahayaan yang baik maka dapat mematikan kuman karena cahaya matahari pagi banyak mengandung sinar ulltraviolet.

Penelitian ini sejalan dengan penelitian Agungnisa (2019) bahwa didapatkan hasil tidak ada hubungan antara pencahayan alami rumah dengan kejadian ISPA pada masyarakat di Desa Kalianget Timur, dengan nilai P.-Value 1.000>0,05 karena kebanyakan rumah responden memiliki tembok dengan cat warna putih sehingga meningkatkan pencahayaan meskipun ventilasinya kurang ${ }^{23}$.
Penelitian ini juga sejalan dengan Dewi (2013) di wilayah kerja Puskesmas Gayamsari intensitas pencahayaan dalam rumah yang memenuhi syarat lebih banyak dari pada intensitas pencahayaan dalam rumah yang tidak memenuhi syarat sebanyak 52,4\% menderita ISPA sedangkan jumlah ISPA pada kategori intensitas pencahayaan dalam rumah yang memenuhi syarat sebanyak $82,6 \%^{24}$.

\section{Hubungan keberadaan anggota keluarga perokok dengan kejadian penyakit ISPA di Kecamatan Wonggeduku Kabupaten Konawe tahun 2019}

Hasil analisis statistik keberadaan anggota keluarga perokok dengan kejadian penyakit ISPA di Kecamatan Wonggeduku disajikan pada table 5 berikut ini.

Table 5.Hubungan keberadaan anggota keluarga perokok dengan kejadian penyakit ISPA di Kecamatan Wonggeduku Kabupaten Konawe tahun 2019.

\begin{tabular}{|c|c|c|c|c|c|c|c|}
\hline \multirow{3}{*}{$\begin{array}{c}\text { Keberadaan } \\
\text { anggota } \\
\text { keluarga } \\
\text { perokok }\end{array}$} & \multicolumn{4}{|c|}{ ISPA } & \multicolumn{2}{|c|}{ Total } & \multirow{2}{*}{$\begin{array}{c}P \\
\text { Value }\end{array}$} \\
\hline & \multicolumn{2}{|r|}{$\mathrm{Ya}$} & \multicolumn{2}{|c|}{ Tidak } & & & \\
\hline & $n$ & $\%$ & $n$ & $\%$ & $n$ & $\%$ & \\
\hline Ada & 42 & 75.0 & 14 & 25.0 & 56 & 100 & 0.008 \\
\hline Tidak Ada & 18 & 46.2 & 21 & 53.8 & 39 & 100 & \\
\hline Total & 60 & 63.2 & 35 & 36.8 & 95 & 100 & \\
\hline
\end{tabular}

Menurut Peraturan Menteri Kesehatan Republik Indonesia nomor 1077/Menkes/PER/V/2011 tentang pedoman penyehatan udara dalam ruang rumah menyebutkan bahwa kualitas udara dalam ruang rumah dipengaruhi oleh beberapa factor salah satunya adalah perilaku merokok didalam rumah yang mempunyai dampak pada bayi dan anak-anak yang orang tuanya perokok yang mempunyai risiko lebih besar terkena gangguan saluran pernafasan dengan gejala sesak nafas, batuk dan lender yang berlebihan ${ }^{25}$.

Asap rokok yaitu campuran asap yang berasal dari pembakaran rokok, pipa atau cerute dan asap yang diisap dari merokok. Campuran asap tersebut lebih dari 40 senyawa diantaranya menyebabkan penyakit kanker, sebagian besarnya sebagai bahan iritan yang kuat. Manusia yang menghisap ETS disebut perokok pasif.Meningkatnya jumlah paparan asap rokok yang dihasilkan ke lingkungan disebabkan oleh banyaknya anggota keluarga yang merokok dengan jumlah batang rokok yang dihisap cukup banyak. Perokok aktif hanya terpaparasap rokok yang dihirup 
sebesar 15 persen. Sementara 85 persen lain dilepaskan dan dihirup oleh perokok pasif ${ }^{26}$.

Hasil penelitian yang di lakukan di Kecamatan Wonggeduku Kabupaten Konawe sebanyak 95 responden terdapat lebih banyak ada anggota keluarga yang memiliki kebiasaan merokok yaitu sebanyak 56 (58,9\%) responden sedangkan yang tidak ada memiliki anggota keluarga yang merokok yaitu $39(41.1 \%)$ responden, dan juga dari hasil penelitian di dapatkan bahwa lebih banyak anggota keluarga responden yang masih memiliki kebiasaan merokok di dalam rumah. Hasil analisis Cros sectionalmenunjukkan bahwa kejadian ISPA pada masyarakat berhubungandengan keberadaan anggota keluarga perokok.

Kecamatan Wonggeduku dari hasil penelitian masih banyak masyarakat yang merokok dan memiliki kebiasaan buruk yaitu merokok dalam rumah sehingga dengan demikian dapat menyebabkan polusi dalam ruangan dimana kita ketahui banyak senyawasenyawa barbahaya dalam asap dari rokok dan apabila terpapar terus-menerus akan menimbulkan gangguan pernapasan. Namun ada pula respoden yang tidak merokok ini disebabkan kerena menderita penyakit asma sehingga di dalam rumah tersebut tidak ada yang merokok, selain itu juga responden tidak merokok juga karena tidak terbiasa merokok sehingga biasanya dalam satu rumah juga tidak merokok.

Penelitian ini sejalan dengan penelitian Firlya Dian Kurniawati (2019) bahwa didapatkan hasil ada hubungan antara kebiasaan merokok dengan kejadian ispa pada masyarakat di semarang, dengan nilai $p$ value $0,000^{27}$.

Penelitian ini juga sejalan dengan Syahidi Dkk., 2016 menyatakan dari Hasil penelitian adanya anggota keluarga yang merokok, diketahui sebanyak 45 orang $(43,3 \%)$ mempunyai anggota keluarga yang merokok di dalam rumah, sebanyak 41 orang $(39,4 \%)$ responden mempunyai anggota keluarga yang merokok di luar rumah, dan sebanyak 18 (17,3\%) responden yang memiliki anggota keluarga yang tidak merokok sehingga ada hubungan yang bermakna antara keberadaan perokok dalam rumah dengan kejadian ISPA pada masyarakat di wilayah kerja puskesmas Kelurahan Tebet Barat, Kecamatan Tebet, Jakarta Selatan ${ }^{28}$

\section{Hubungan penggunaan anti nyamuk bakar dengan kejadian penyakit ISPA di Kecamatan Wonggeduku Kabupaten Konawe tahun 2019}

Hasil analisis statistik penggunaan anti nyamuk bakar dengan kejadian penyakit ISPA di Kecamatan Wonggeduku disajikan pada table 6 berikut ini.

Table 6.Hubungan penggunaan anti nyamuk bakar dengan kejadian penyakit ISPA di Kecamatan Wonggeduku Kabupaten Konawe tahun 2019.

\begin{tabular}{|c|c|c|c|c|c|c|c|}
\hline \multirow{3}{*}{$\begin{array}{c}\text { Penggunaan } \\
\text { anti nyamuk } \\
\text { bakar }\end{array}$} & \multicolumn{4}{|c|}{ ISPA } & \multirow{2}{*}{\multicolumn{2}{|c|}{ Total }} & \multirow{3}{*}{$\begin{array}{r}P \\
\text {-Value }\end{array}$} \\
\hline & \multicolumn{2}{|c|}{$\mathrm{Ya}$} & \multicolumn{2}{|c|}{ Tidak } & & & \\
\hline & $\mathrm{n}$ & $\%$ & $n$ & $\%$ & $n$ & $\%$ & \\
\hline TMS & 40 & 76.9 & 12 & 23.1 & 52 & 100 & \\
\hline MS & 20 & 46.5 & 23 & 53.5 & 42 & 100 & 0.004 \\
\hline Total & 60 & 63.2 & 35 & 36.8 & 95 & 100 & \\
\hline
\end{tabular}

Kandungan berbahaya pada obat nymauk bergantung pada konstransi racun dan jumlah pemakaiannya.resiko terbesar yaitu jenis obat anti nyamuk cair memiliki konsentrasi yang berbeda karena cairan yang dikeluarkan akan berubah menjadi gas. sedangkan obat nyamuk listrik atau elektrik resikonya lebih kecil lagi karena bekerja dengan cara mengeluarkan asap dengan daya elektrik. anti nyamuk bakar juga dapat menjadi salah satu penyebab pencemaran udara di dalam rumah. Walaupun konsentrasinya kecil, namun zat yang terdapat dalam obat anti nyamuk bakar dapat menyebabkan batuk dan iritasi hidung ${ }^{29}$.

Hasil penelitian pada masyarakat di wilayah kerja Puskesmas Wonggeduku yang menggunakan anti nyamuk bakar sebanyak $54,7 \%$ sedangkan yang tidak menggunakan anti nyamuk bakar adalah 45,3\%. Masyarakat yang didalam rumahnya menggunakan anti nyamuk bakar mempunyai resiko tinggi terkena penyakit ISPA. dari 60 yang menderita penyakit ISPA di dapatkan 40 yang menderita penyakit ISPA di sebabkan karena penggunaan anti nyamuk bakar sedangkan yang tidak menggunakan anti nyamuk bakar resiko terkena penyakit ISPA jauh lebih sedikit dibandingkan yang menggunakan.

Hasil uji chi square diperoleh p-value 0,004 $<0,05$ sehingga dapat disimpulkan bahwa ada hubungan yang bermakna antara penggunaan anti nyamuk bakar dengan kejadian penyakit ISPA di Kecamatan Wonggeduku Kabupaten Konawe tahun 2019. Adanya hubungan yang bermakna antara 
penggunaan anti nyamuk bakar dengan kejadian penyakit ISPA di sebabkan karena di setiap rumah memilliki kebiasaan menggunakan anti nyamuk bakar setiap harinya dan penempatan anti nyamuk juga tidak memenuhi syarat, berdasarkan penelitian masyarakat banyak menempatkan anti nyamuk bakar di sudut-sudut rumah yang jauh dari ventilasi. Anti nyamuk bakar jenis oles, elektrik dan kelambu lebih aman dari pada menggunakan anti nyamuk bakar karena tidak menimbulkan asap yang dapat menyebabkan pencemaran udara, namun jika masih tetap menggunakan anti nyamuk bakar maka simpan di tempat yang dekat dengan ventilasi.

Penelitian ini sejalan dengan Saleh Dkk., 2017 menyatakan dari 91 rumah di Kecamatan Mariso, diketahui bahwa rumah yang menggunakan anti nyamuk tidak memenuhi syarat adalah 61 rumah $(67,0 \%)$, dimana kasus ISPA pada kelompok responden dengan anti nyamuk yang tidak memenuhi syarat adalah $85,2 \%$ sedangkan yang menggunakan anti nyamuk yang memenuhi syarat adalah 30 rumah $(33,0 \%)$, dimana kasus ISPA pada kelompok responden dengan anti nyamuk yang memenuhi syarat adalah sebesar $46,7 \%^{30}$.

Penelitian ini sejalan juga dengan Syahidi Dkk., 2016 menyatakan dari Hasil penelitian menunjukkan bahwa ada $82,9 \%$ responden yang tinggal di rumah dengan kepadatan hunian yang tidak memenuhi syarat. Hasil analisis menunjukkan bahwa ada hubungan yang bermakna antara kepadatan hunian dengan kejadian ISPA pada masyarakat ${ }^{31}$.

\section{SIMPULAN}

Tidak terdapat hubungan antara ventilasi rumah dengan kejadian penyakit ISPA Pada masyarakat karena sebagian besar ventilasi masyarakat di Kecamatan Wonggeduku Kebupaten Konawe telah memenuhi syarat.adahubungan antara kepadatan hunian dengan kejadian penyakit ISPA pada Masyarakat Kecamatan Wonggeduku Kabupaten Konawe.Artinya tingkat kepadatan hunian masyarakat memberikan peluang besar untuk kejadian ISPA.tidak ada hubungan antara pencahayaan alami rumah pada pagi hari dan siang hari dengan kejadian penyakit ISPA,Artinya pencahayaan sudah sangat baik sehingga tidak menyebabkan kejadian ISPA. Sedangkan pencahayaan alami rumah pada sore hari tidak berhubungan dengan kejadian penyakit ISPA Pada masyarakat Kecamatan Wonggeduku Kabupaten Konawe.Artinya cahaya yang kurang pada sore hari tidak menyebabkan kejadian ISPA pada masyarakat Wonggeduku.Ada Hubungan antara keberadaan anggota keluarga perokok dengan kejadian penyakit ISPA pada masyarakat Kecamatan Wonggeduku Kabupaten Konawe.Artinya tingginya kebiasaan masyarakat merokok menyebabkan kejadian ISPA pada masyarakat tersebut.Ada Hubungan antara penggunaan anti nyamuk bakar dengan kejadian penyakit ISPA pada Masyarakat Kecamatan Wonggeduku Kabupaten Konawe.

\section{SARAN}

Agar Masyarakatlebih memperhatikan jumlah kepadatan hunian di dalam rumah, karena semakin padat jumlah hunian maka kemungkinan perpindahan penyakit akan semakin cepat dan mudah sehingga dapat memungkinkan terjadi penyakit ISPA dan penyakit menular lain.Penggunaan obat nyamuk bakar sebaiknya mengurangi pemakaian anti nyamuk tersebut dan beralih menggunakan kelambu, lotion atau menggunakan pengusir nyamuk listrik sehinga resiko untuk terkena penyakit ISPA dapat di cegah.Pengetahuan dampak dari rokok perlu ditingkatkan karena dapat membahayakan kesehatan perokok, sehingga dapat memotifasi orang lain yang merokok agar dapat berhenti merokok mengigat dampak luas yang yang dapat di timbulkan oleh rokok.Bagi Pihak Puskesmas agar meningkatkan peran serta masyarakat melalui promosi baik itu melalui penyuluhan kesehatan dengan mengikutsertakan kader, bagian kesehatan lingkungan, perangkat desa dan lain-lain sebagai tujuan untuk meningkatkan pengetahuan masyarakat di bidang kesehatan lingkungan.Kuhusunya tentang penyehatan lingkungan pemukiman/perumahan/sanitasi rumah, terutama Pencegahan Infeksi Saluran Pernapasan Akut (ISPA) pada masyarakat. Sedangkan Peneliti Selanjutnya, Dapat dilaksanakan penelitian berikutnya dengan menambahkan variabel, suhu rumah, jenis lantai, jenis atap, dan polusi udara dalam rumah.

\section{DAFTAR PUSTAKA}

1. World Health Organization.2019.Documents on acute respiratory infections. https://www.who.int/maternal child adolescent/ documents/respiratory/en/.

2. Riset Kesehatan Dasar. (2018). Badan Penelitian dan Pengembangan Kesehatan Kementerian Kesehatan RI. Jakarta. 
3. Dinas Kesehatan Provinsi Sulawesi Tenggara. 2018. Profil Kesehatan Sulawesi Tenggara. Kendari.

4. Dinas Kesehatan Kota Kendari, 2019. Profil Kesehatan Kota Kendari.

5. Data Puskesmas Wonggeduku, 2019. Profil Kesehtan Kabupaten Konawe.

6. BPS Konawe. 2015. Kabupaten Wonggeduku dalam Angka 2019

7. Data Puskesmas Wonggeduku, 2019. Profil Kesehtan Kabupaten Konawe.

8.

afrizal, S. (2017). Hubungan Ventilasi, Lantai, Dinding,dan Atap dengan Kejadian Ispa Pada Balita Di Blang Muko. Prosiding Seminar Nasional Ikakesmada "Peran Tenaga Kesehatan Dalam Pelaksanaan SDGs,". vol.1(1):41-48.

9. Kementerian Kesehatan RI (2011) Peraturan Menteri Kesehatan Republik Indonesia Nomor 1077/Menkes/Per/V/2011 tentang Pedoman Penyehatan Udara Dalam Ruang Rumah. Jakarta

10. Sormin KR. 2012. Hubungan karakteristik dan prilaku pekerja yang terpajan debu kapas dengan kejadian ISPA di PT. Unitex tahun 2011 (skripsi). Depok Universitas Indonesia.

11. Notoatmodjo, S. (2010). Kesehatan Masyarakat Ilmu dan Seni. Jakarta: Rineka Cipta..

12. Kementerian Kesehatan RI (2011) Peraturan Menteri Kesehatan Republik Indonesia Nomor 1077/Menkes/Per/V/2011 tentang Pedoman Penyehatan Udara Dalam Ruang Rumah

13. Agustina.2018.Analysis of Housing Environmental Factors with Arrival Disease Events in Communities in Kelurahan Oenesu District Kupang. Health Polytechnic of Kupang. Nusa Cendana University

14. Agungnisa, A. (2019). Physical Sanitation of the House that Influence the Incidence of ARI in Children under Five in Kalianget Timur Village. Jurnal Kesehatan Lingkungan, 11(1), 1.

15. Marhamah, A. A. Arsin, dan Wahiduddin. (2013). Faktor yang Berhubungan dengan Kejadian ISPA pada Anak Balita di Desa Bontongan, Kabupaten Enrekang. Universitas Hasanuddin

16. Kementerian Kesehatan RI (2011) Peraturan Menteri Kesehatan Republik Indonesia Nomor 1077/Menkes/Per/V/2011 tentang Pedoman Penyehatan Udara Dalam Ruang Rumah

17. Achmadi, U.F.(2014). Manajemen Penyakit Berbasis Wilayah. Jakarta. UI-Press.
18. Taha, L., dan Ryzdayani, D. (2018). Kondisi Fisik Rumah Dengan Kejadian Penyakit Ispa Di Wilayah Kerja Puskesmas Moncobalang Kecamatan Barombong Kabupaten Gowa. Jurnal Sulolipu. Vol. 18(1):24-29.

19. Wahyuningsih, S., Raodhah, S., \& Basri, S. (2017). Infeksi Saluran Pernafasan Akut (ISPA) pada Balita di Wilayah Pesisir Desa Kore Kecamatan Sanggar Kabupaten Bima. HIGIENE: Jurnal Kesehatan Lingkungan, 3(2), 97-105.

20. Hogarh, J. N., Antwi-Agyei, P., \& Obiri-Danso, K. (2016). Application of mosquito respellent coils and associated self-reported health issues in Ghana. Malaria Journal, 15(1), 1-7.

21. Meita PRR. Nurmaini dan Dharma S. (2013). Hubungan Fisik Rumah dengan Kejadian ISPA pada Balita di Sekitar Usaha Pembuatan Batu Bara di Desa Tanjung Mulia Kecamatan Pagar Merbau Kabupaten Deli Serdang Tahun 2013.

22. Suryani, I., Edison, and J. Nazar. (2015). Hubungan Lingkungan Fisik dan Tindakan Penduduk dengan Kejadian ISPA pada Balita di Wilayah Kerja Puskesmas Lubuk Buaya. Jurnal Kesehatan Andalas. Vol 4(1): 157-167.

23. Agungnisa, A. (2019). Physical Sanitation of the House that Influence the Incidence of ARI in Children under Five in Kalianget Timur Village. Jurnal Kesehatan Lingkungan, 11(1), 1.

24. Dwi A.,C. (2012). Hubungan Kondisi Fisik Rumah dengan Kejadian ISPA pada Balita di Wilayah Kerja Puskesmas Gayamsari Kota Semarang. Jurnal Kesehatan Masyarakat. Vol. 1(2).

25. Kusumawati, Ita. (2010). Hubungan antara status merokok anggota keluarga dengan lama pengobatan ISPA balita di kecamatan jenawi. unpublished thesis, program pasca sarjana kedokteran keluarga, universitas sebelas maret, surakarta.

26. Kurniawati, FD., (2019). The Effect Of Exclusive Breastfeeding, Nutrition Status, Smoking Habits And Workplace Distance Towards Frequency Of Acute Respiratory Tract Infection In Toddlers. Universitas negeri semarang. Public Health Perspectives Journal.vol.4(2):83-93.

27. Syahidi, M. H., Gayatri, D., dan Bantas, K. (2016). Faktor-faktor yang Mempengaruhi Kejadian Infeksi Saluran Pernapasan Akut (ISPA) pada Anak Berumur 12-59 Bulan di Puskesmas Kelurahan Tebet Barat, Kecamatan Tebet, Jakarta Selatan, Tahun 2013. Jurnal Epidemiologi Kesehatan Indonesia. 1(1):23-27. 
28. Sinaga, epiria keristina. 2012 kualitas lingkungan fisik rumah dengan kejadian infeksi saluran pernafasan akut (ISPA) pada balita di wilayah kerja puskesmas kelurahan warakes kecamatan tanjung priuk jakarta utara tahun 2012. skripsi.UI.Depok

29. Saleh, M. dan Gafur, AS. (2017). Hubungan Sumber Polutan dalam Rumah Dengan Kejadian Infeksi Saluran Pernafasan Akut pada Balita di Kecamatan Mariso Kota Makassar. Kesehatan Lingkungan. 3(3):946-952.

30. Syahidi, M. H., Gayatri, D., dan Bantas, K. (2016). Faktor-faktor yang Mempengaruhi Kejadian Infeksi Saluran Pernapasan Akut (ISPA) pada Anak Berumur 12-59 Bulan di Puskesmas Kelurahan Tebet Barat, Kecamatan Tebet, Jakarta Selatan, Tahun 2013. Jurnal Epidemiologi Kesehatan Indonesia. 1(1):23-27. 